\title{
A Study on Dietary Practices and Nutritional Awareness among Adolescent Girls
}

\author{
K. Spandana Deepika* and R. Geetha Reddy
}

Department of Extension Education and Communication Management, College of Home Science, Hyderabad, Professor Jayashankar Telangana State Agricultural University, Telangana, India

*Corresponding author

\section{Keywords}

Adolescent girls, Dietary practices, Nutritional awareness, Nutrition education

Article Info

Accepted: 17 June 2019 Available Online: 10 July 2019
Adolescence is the transition period between childhood and adulthood, a window of opportunity for the improvement of nutritional status and correcting poor dietary practices. The World Health Organization (WHO) defines an adolescent as any person between ages 10 and 19. The present was conducted to study the dietary practices and nutritional awareness of adolescent girls of Mahabubnagar district Telangana. Findings showed that when compared to urban adolescents, rural adolescents were less consuming green leafy vegetables and fruits. The majority of rural adolescent girls $(73 \%)$ have moderate nutritional awareness and in urban majority $(57 \%)$ of the respondents have high nutritional awareness. They need school-based nutrition education to improve their dietary practices and nutritional awareness of adolescent girls.

\section{Introduction}

The word adolescence is Latin in origin, derived from the verb adolescere, which means "to grow into adulthood." Adolescence is a time of moving from the immaturity of childhood into the maturity of adulthood. These transitions are biological, cognitive, social, and emotional. Adolescent females are more prone to nutritional difficulties than adolescent males. In early childhood (0-4 years), the available international evidence suggests that differences in nutritional status between girls and boys are statistically negligible. A healthy diet should include a wide variety of nutritious foods for sufficient intake of all nutrients, including vitamins and minerals. Foods to include are breads, pastas, lean meats, fish, fruits and vegetables. A healthy diet can help you maintain a healthy body weight and decrease your risk of many diet-related chronic diseases, such as 
cardiovascular disease, type 2 diabetes and some cancers. Healthy diet is a diet that helps to maintain or improve overall health. A healthy diet provides the body with essential nutrition: fluid, macronutrients, micronutrients, and adequate calories.

\section{Materials and Methods}

The study was conducted in Mahabubnagar district of Telangana. Expost-facto research design was followed for the study. Simple random sampling procedure was used for selection of respondents. A total of 60 adolescent girls, 30 adolescent girls from rural area and 30 adolescent girls from urban area who were studying in government and private schools were randomly selected for the study.Data was collected with the help of questionniare developed by YabsiraMelaku (2018) was used with slight modifications for assessing the dietary practices of rural and urban adolescent girls. The specific objectives for the study are as under.

Melaku et al., (2018) studied optimal dietary practices and nutritional knowledge of school adolescent girls. The study pointed that common nutritional problem of adolescent girls was malnutrition. The author revealed that majority $(55.8 \%)$ of the adolescent girls had good nutritional knowledge that they learned from the school $(86.6 \%)$. The occupational status of parents plays a major role on the dietary practices of adolescent girls. The author suggested that it can be further improved with school-based nutrition education, nutrition sensitive interventions and comprehensive community based programs to reach both the students and their families.

Pavithran and Bant (2018) revealed the nutritional status of adolescent school girls residing in rural areas of Dharwad district, India. They studied their socio demographic profile, anthropometric measurements (height, weight and BMI) and dietary pattern of rural adolescent girls. The study revealed that rural adolescent girls - $14.9 \%$ of were underweight for their age and based on BMI, $25.2 \%$ were under-nourished and $3.7 \%$ were over nourished. And there is high prevalence of under nutrition among adolescent girls and it is associated with micronutrient deficiencies like anemia. Nutritional awareness should be done to improve the nutritional needs of adolescent girls in rural areas.

Nair et al., (2017) studied the nutritional status of adolescent girls in a rural area of a district of Maharashtra. The study was a community based cross sectional study done among 583 adolescent girls in 10 villages of a district. In this study the prevalence of underweight (36.54\%) and stunting (48.37\%) was found, moreover under nutrition was high among adolescent girls. To improve their nutritional status appropriate health education and nutrition intervention should be directed towards them.

The main objectives include, to study the general profile of rural and urban adolescent girls; to study the dietary practices of rural and urban adolescent girls and also to study the nutritional awareness of rural and urban adolescent girls.

\section{Results and Discussion}

From the above Table 1, it is seen that majority of the respondents both in rural and urban population in the present study fall under $11-14$ years $(80 \%$ \& $77 \%$ respectively. The educational level of the respondents, who were classified into three categories, eighth class, ninth class and tenth class. In rural majority $(100 \%)$ of the respondents are from ninth class followed by eighth class $(0 \%)$ and tenth class $(0 \%)$. In urban majority $(63 \%)$ of the respondents are from ninth class followed by eighth class $(23 \%)$, tenth class $(13 \%)$. By 
considering the total respondents, majority $(82 \%)$ are from ninth class followed by $(12 \%)$ from eighth class and $(6 \%)$ from tenth class. Table 1 revealed that majority of the respondents were from ninth class.

The type of the family the respondents were classified into two categories namely joint and nuclear families. In rural majority of the respondents are from nuclear families $(87 \%)$ followed by joint family (13\%). In urban area majority of the respondents are from nuclear family $(90 \%)$ and only $(10 \%)$ of the respondents are from joint family. The reason for the above distribution could be because tradition of having Joint family system was deceasing year by year and people preferred to live in nuclear families for the sake of better harmony and satisfaction of basic needs, lesser responsibilities, privacy, and also hey felt that they can take better care for their family health and nutrition in the nuclear families.

Further, the educational level of the respondent parent's, who were classified into six categories namely illiterate, primary school, middle school, high school, college education, graduation \& above. Table 1 clearly indicated that respondents i.e., In rural majority $(87 \%)$ of the respondent's fathers are illiterates followed by middle school education $(7 \%)$, primary school education (3\%), high school education (3\%), College education (0\%) and Graduation \& Above $(0 \%)$. In urban majority $(27 \%)$ of the respondent's fathers have education upto High School and College education followed by Middle School (20\%), Illiterate (17\%), Graduation \& Above (6\%) and Primary School (3\%). Similarly, in rural area majority $(67 \%)$ of the respondent's mothers are illiterates followed by high school education (13\%), primary school education (10\%, middle school education (10\%), College education $(0 \%)$ and Graduation \& Above
$(0 \%)$. In urban majority (27\%) of the respondent's mothers have education up to High School and Middle School followed by Illiterate (20\%), College education (7\%) Graduation \& Above (7\%) and Primary School (0\%).

From the Table 2, it was observed that in rural and urban, more than half $(60 \%)$ of the respondents opined that they were eating cereal and pulse products occasionally. In rural $(26 \%)$ and in urban $(64 \%)$ of the respondents were consuming green leafy vegetables in their daily menu.

In rural $(13 \%)$ and in urban $(77 \%)$ of the respondents were having fruits and very minute percentage were skipping their meals in the name of fasting. Another important point was that in rural and in urban less than 50 percent of the respondents was having milk and egg in their daily meal pattern. In rural $(53 \%)$ and in urban $(83 \%)$ of the respondents were following three meal pattern per day and in rural (50\%) and in urban (90\%) of the respondents were opined that they daily drink cool beverages. When compared with rural adolescents, urban adolescents food habits were different and majority $(77 \%)$ of them were eating junk food it was noted but in rural less than half $(47 \%)$ of the respondents were eating junk food. For every item, the urban adolescent girls' food habits were good i.e., eating fruits and green leafy vegetables than rural adolescent girls. This result may be due to their low income levels and non - availability of foods like junk foods to them.

Respondents were asked to indicate their meal pattern whether they were eating every meal or skipping any meal in their daily life.

From the Table 3, it was revealed that the meal pattern of the adolescent girls was same, but some respondents in rural area were 
skipping their breakfast, both the groups were not skipping their lunch. The reason was due to mid day meal programmme the children who were studying in government school are having their lunch at school and there is no chance of missing their meal. When compared with rural adolescent girls, urban adolescent girls were following all these seven meals pattern. It was observed from the Table 4 that in rural majority (73\%) of the respondents had moderate level nutritional awareness followed by $(27 \%)$ low level nutritional awareness and
(0\%) high level nutritional awareness. In urban, majority (57\%) of the respondents have high level nutritional awareness followed by $(43 \%)$ moderate level nutritional awareness and (0\%) low level nutritional awareness. By taking into consideration the total respondents majority (58\%) of the respondents have middle nutritional awareness followed by (28\%) high nutritional awareness and (13\%) low nutritional awareness.

Table.1 General profile of the respondents (rural and urban adolescent girls)

\begin{tabular}{|c|c|c|c|c|c|c|c|}
\hline \multirow[t]{2}{*}{ S.No } & \multirow[t]{2}{*}{ Variable } & \multicolumn{2}{|c|}{$\begin{array}{l}\text { Rural } \\
(\mathbf{n}=30)\end{array}$} & \multicolumn{2}{|c|}{$\begin{array}{l}\text { Urban } \\
(\mathbf{n}=30)\end{array}$} & \multicolumn{2}{|c|}{$\begin{array}{c}\begin{array}{c}\text { Total }=60 \\
(n=60)\end{array}\end{array}$} \\
\hline & & $\mathbf{F}$ & $\%$ & $\mathbf{F}$ & $\%$ & $\mathbf{F}$ & $\%$ \\
\hline \multirow[t]{3}{*}{1} & \multicolumn{7}{|l|}{ Age } \\
\hline & 11-14 Years & 24 & 80 & 22 & 73 & 46 & 77 \\
\hline & 14-17 Years & 6 & 20 & 8 & 27 & 14 & 23 \\
\hline \multirow[t]{4}{*}{2} & \multicolumn{7}{|l|}{ Level of Education } \\
\hline & VIII class & 0 & 0 & 7 & 23 & 7 & 12 \\
\hline & IX class & 30 & 100 & 19 & 63 & 49 & 82 \\
\hline & $\mathrm{X}$ class & 0 & 0 & 4 & 13 & 4 & 6 \\
\hline \multirow[t]{3}{*}{3} & \multicolumn{7}{|l|}{ Type of family } \\
\hline & Joint & 4 & 13 & 3 & 10 & 7 & 12 \\
\hline & Nuclear & 26 & 87 & 27 & 90 & 53 & 88 \\
\hline \multirow[t]{6}{*}{4} & \multicolumn{7}{|l|}{ Father's Education } \\
\hline & Illiterate & 26 & 87 & 5 & 17 & 31 & 52 \\
\hline & Primary School & 1 & 3 & 1 & 3 & 2 & 3 \\
\hline & Middle School & 2 & 7 & 6 & 20 & 8 & 13 \\
\hline & High School & 1 & 3 & 8 & 27 & 9 & 16 \\
\hline & College education & 0 & 0 & 8 & 27 & 8 & 13 \\
\hline \multirow[t]{6}{*}{5} & \multicolumn{7}{|l|}{ Mother's Education } \\
\hline & Illiterate & 20 & 67 & 6 & 20 & 26 & 43 \\
\hline & Primary School & 3 & 10 & 0 & 0 & 3 & 6 \\
\hline & Middle School & 3 & 10 & 8 & 27 & 11 & 18 \\
\hline & High School & 4 & 13 & 8 & 27 & 12 & 20 \\
\hline & College education & 0 & 0 & 6 & 7 & 6 & 10 \\
\hline
\end{tabular}


Table.2 To study the dietary practices of rural and urban Adolescent girls

\begin{tabular}{|c|c|c|c|c|c|c|c|}
\hline \multirow[t]{2}{*}{ S.No } & \multirow[t]{2}{*}{ Dietary food habits } & \multicolumn{3}{|c|}{ Rural Population $(\mathrm{n}=30)$} & \multicolumn{3}{|c|}{ Urban Population $(\mathrm{n}=\mathbf{3 0})$} \\
\hline & & $\begin{array}{l}\text { Daily } \\
\text { F (\%) }\end{array}$ & $\begin{array}{c}\text { Occasionally } \\
\text { F }(\%)\end{array}$ & $\begin{array}{l}\text { Never } \\
\text { F }(\%)\end{array}$ & $\begin{array}{l}\text { Daily } \\
\text { F (\%) }\end{array}$ & $\begin{array}{c}\text { Occasionally } \\
\text { F }(\%)\end{array}$ & $\begin{array}{l}\text { Never } \\
\text { F (\%) }\end{array}$ \\
\hline 1. & $\begin{array}{l}\text { How often do you eat cereal } \\
\text { and pulse products? }\end{array}$ & $5(17)$ & $19(63)$ & $6(20)$ & $7(23)$ & $18(60)$ & $5(17)$ \\
\hline 2. & $\begin{array}{l}\text { How often do you eat green } \\
\text { leafy vegetables? }\end{array}$ & $8(26)$ & $20(67)$ & 2(7) & $19(64)$ & $10(33)$ & 1(3) \\
\hline 3. & How often do you eat fruits? & $4(13)$ & 23(77) & $3(10)$ & $23(77)$ & $5(17)$ & $2(6)$ \\
\hline 4. & How often do you drink milk? & 9(30) & $14(47)$ & $7(23)$ & $14(48)$ & $8(26)$ & $8(26)$ \\
\hline 5. & How often do you eat sweets? & 3(10) & $25(83)$ & $2(7)$ & $5(17)$ & $22(73)$ & $3(10)$ \\
\hline 6. & How often do you eat egg? & $6(20)$ & $14(47)$ & $10(33)$ & $12(40)$ & $15(50)$ & 3(10) \\
\hline 7. & $\begin{array}{l}\text { Do you skip your meal in the } \\
\text { name of fasting? }\end{array}$ & 1(3) & $9(31)$ & $20(66)$ & 1(3) & $6(20)$ & $23(77)$ \\
\hline 8. & $\begin{array}{l}\text { How often do you drink tea / } \\
\text { coffee? }\end{array}$ & $12(40)$ & $12(40)$ & $6(20)$ & 9(30) & $14(47)$ & $7(23)$ \\
\hline 9. & $\begin{array}{l}\text { How often do you eat non } \\
\text { vegetarian foods? }\end{array}$ & $7(23)$ & $22(74)$ & 1(3) & 9(30) & $20(66)$ & 1(3) \\
\hline 10. & $\begin{array}{l}\text { Do your family members } \\
\text { force you to eat more? }\end{array}$ & $8(27)$ & $15(50)$ & $7(23)$ & $23(77)$ & $7(23)$ & $\mathbf{0}(\mathbf{0})$ \\
\hline 11. & $\begin{array}{l}\text { Do you follow three meal } \\
\text { pattern per day? }\end{array}$ & $16(53)$ & $14(47)$ & $0(0)$ & $25(83)$ & $5(17)$ & $0(0)$ \\
\hline 12. & $\begin{array}{l}\text { How often do you drink cool } \\
\text { beverages? }\end{array}$ & $15(50)$ & $15(50)$ & $\mathbf{0}(\mathbf{0})$ & $27(90)$ & $3(10)$ & $0(0)$ \\
\hline 13. & $\begin{array}{l}\text { How often do you consume } \\
\text { variety of foods? }\end{array}$ & $8(27)$ & $10(33)$ & $12(40)$ & $15(50)$ & $11(37)$ & $4(13)$ \\
\hline 14. & $\begin{array}{l}\text { How often do you eat junk } \\
\text { foods? }\end{array}$ & $14(47)$ & 2(6) & $14(47)$ & $23(77)$ & 2(6) & $5(17)$ \\
\hline 15. & $\begin{array}{l}\text { How often do you suffer from } \\
\text { any health issue? }\end{array}$ & $0(0)$ & 28(93) & 2(7) & $0(0)$ & $18(60)$ & $12(40)$ \\
\hline
\end{tabular}


Table.3 To study the meal pattern of rural and urban Adolescent girls

\begin{tabular}{|r|l|c|c|c|c|c|c|}
\hline S.No & $\begin{array}{l}\text { Meal } \\
\text { pattern }\end{array}$ & \multicolumn{3}{|c|}{ Rural Population (n =30) } & \multicolumn{3}{c|}{ Urban Population (n=30) } \\
\hline \multicolumn{2}{|c|}{$\begin{array}{c}\text { Daily } \\
\text { F (\%) }\end{array}$} & $\begin{array}{c}\text { Occasionally } \\
\text { F (\%) }\end{array}$ & $\begin{array}{c}\text { Never } \\
\text { F (\%) }\end{array}$ & $\begin{array}{c}\text { Daily } \\
\text { F (\%) }\end{array}$ & $\begin{array}{c}\text { Occasionally } \\
\text { F (\%) }\end{array}$ & $\begin{array}{c}\text { Never } \\
\text { F (\%) }\end{array}$ \\
\hline 1. & $\begin{array}{l}\text { Before } \\
\text { breakfast }\end{array}$ & $20(66.37)$ & $9(30.00)$ & $1(3.33)$ & $8(26.67)$ & $18(60.00)$ & $4(13.33)$ \\
\hline 2. & Breakfast & $16(53.33)$ & $9(30.00)$ & $5(16.67)$ & $16(53.33)$ & $14(46.67)$ & $0(0.00)$ \\
\hline 3. & $\begin{array}{l}\text { Interval } \\
\text { time }\end{array}$ & $25(83.33)$ & $4(13.33)$ & $1(3.33)$ & $22(73.33)$ & $4(13.33)$ & $4(13.33)$ \\
\hline 4. & Lunch & $30(100.00)$ & $0(0.00)$ & $0(0.00)$ & $30(100.00)$ & $0(0.00)$ & $0(0.00)$ \\
\hline 5. & $\begin{array}{l}\text { Evening } \\
\text { snacks }\end{array}$ & $4(13.33)$ & $23(76.67))$ & $3(10.00)$ & $16(53.33)$ & $12(40.00)$ & $2(6.67)$ \\
\hline 6. & Dinner & $28(93.33)$ & $1(3.33)$ & $1(3.33)$ & $26(86.67)$ & $4(13.33)$ & $0(0.00)$ \\
\hline 7. & Bed time & $3(10.00)$ & $26(86.67)$ & $1(3.33)$ & $14(46.67)$ & $11(36.67)$ & $5(16.67)$ \\
\hline
\end{tabular}

Table.4 Distribution of respondents according to their nutritional awareness

\begin{tabular}{|l|l|c|c|c|c|c|c|}
\hline S.No & $\begin{array}{l}\text { Nutritional } \\
\text { awareness }\end{array}$ & \multicolumn{2}{|c|}{$\begin{array}{c}\text { Rural } \\
(\mathbf{n = 3 0})\end{array}$} & \multicolumn{2}{|c|}{$\begin{array}{c}\text { Urban } \\
(\mathbf{n = 3 0})\end{array}$} & \multicolumn{2}{|c|}{$\begin{array}{c}\text { Total } \\
(\mathbf{n = 6 0})\end{array}$} \\
\cline { 3 - 9 } & & Frequency & $\begin{array}{c}\text { Percentage } \\
(\mathbf{\%})\end{array}$ & Frequency & $\begin{array}{c}\text { Percentage } \\
(\mathbf{\%})\end{array}$ & $\mathbf{F}$ & $\%$ \\
\hline $\mathbf{1}$ & $\begin{array}{l}\text { Low level } \\
(0-6)\end{array}$ & 8 & 27 & 0 & 0 & 8 & 13 \\
\hline $\mathbf{2}$ & $\begin{array}{l}\text { Moderate } \\
\text { level (7-13) }\end{array}$ & 22 & 73 & 13 & 43 & 35 & 58 \\
\hline $\mathbf{3}$ & $\begin{array}{l}\text { High level } \\
(14-20)\end{array}$ & 0 & 0 & 17 & 57 & 17 & 28 \\
\hline & Total & $\mathbf{3 0}$ & $\mathbf{1 0 0 . 0}$ & $\mathbf{3 0}$ & $\mathbf{1 0 0 . 0}$ & $\mathbf{6 0}$ & $\mathbf{1 0 0 . 0}$ \\
\hline
\end{tabular}

In conclusion, the adolescent girls are the backbone for the development of a country. The majority $(82 \%)$ are from ninth class followed by (12\%) from eighth class and $(6 \%)$ from tenth class. In rural majority $(87 \%)$ of the respondent's fathers are illiterates and in urban majority $(27 \%)$ of the respondent's fathers have education upto High School and college education. In rural majority $(87 \%)$ of the respondent's mothers were illiterates and in urban majority $(27 \%)$ of the respondent's mothers have education up to High School and Middle School. The dietary practices of rural and urban adolescents were similar in some foods. When compared with urban adolescents, rural adolescents were not eating green leafy vegetables and fruits. The urban adolescents should decrease the consumption of having junk foods. In rural In total, majority $(58 \%)$ of the respondents have middle nutritional awareness followed by $(28 \%)$ high nutritional awareness and $(13 \%)$ 
low nutritional awareness The adolescent girls dietary practices and nutritional awareness will definitely show an impact on their healthy and bright future. To achieve anything in one's own life, that person should be healthy.

\section{References}

Awasthi, R., Srivastava, A., Dixit, A.K and Sharma, M. 2016. Nutritional status of adolescent girls in urban slums of Moradabad: a cross sectional study. International Journal of Community Medicine and Public Health. 3(1): 276280.

Choudhary, K., Shekhawat, K and Kawatra, A. 2014. A cross sectional study to assess nutritional status of adolescent girls at a government senior secondary girls' school at Bikaner, Rajasthan. Indian Journal of Community Health. 26: 318-321.

Joshi, S.M., Likhar. S., Mishra, K., Agarwal, S.S and Shukla, U. 2014. A study of nutritional status of adolescent girls in rural area of Bhopal district. National Journal of Community Medicine 5(2):191-194.

Komala, M and Rayanagoudar, S.S. 2015. Nutritional status of young girls of Gadag District. International Journal of Research. 2(1): 13-20.
Melaku, Y., Dirara, A., Fryissab, G.T and Tamirua, D. 2018. Optimal dietary practices and nutritional knowledge of school adolescent girls in Jimma Town, South West Ethiopia. International Journal of Adolescence and Youth. 23(3): 299-307.

Nair, A., Doibale, M.K., Kuril, B.M and Domple, V.K. 2017. Study of nutritional status of adolescent Girls in a rural area of a district of Maharashtra. International Journal of Community Medicine and Public Health. 4(12): 4617-4622.

Pavithran, S and Bant, D.D. 2018. Nutritional status of adolescent school girls residing in rural areas of Dharwad district, India: a cross sectional study. International Journal of Community Medicine and Public Health. 5(7):2761-2765.

Sinha, S., Kumar. S., Kumari, S., Gupta, P and Beena, S. 2017. A study on the morbidity pattern in adolescent school girls. International Journal of Community Medicine and Public Health. 4(6): 1901-1905.

Sinha, S., Singh, R.B. 2016. A study on diet and nutritional status among adolescent girls in Lucknow district, India. International Journal of Community Medicine and Public Health. 3(8): 2019-2025.

\section{How to cite this article:}

Spandana Deepika, K. and Geetha Reddy, R. 2019. A Study on Dietary Practices and Nutritional Awareness among Adolescent Girls. Int.J.Curr.Microbiol.App.Sci. 8(07): 21082114. doi: https://doi.org/10.20546/ijcmas.2019.807.253 